Section Editor

Mitchell S.V. Elkind, MD, MS

Brian H. Walsh, MB $\mathrm{BCh}, \mathrm{PhD}$

Fiona M. Baumer, MD

Miya E. Bernson-Leung, MD

Paul Lerou, MD

Jurriaan M. Peters, MD

Correspondence to

Dr. Walsh:

brian.walsh2@childrens.harvard. edu

\section{Teaching Video NeuroImages: Nonepileptic myoclonus in a neonate following severe hypoxic-ischemic injury}

自

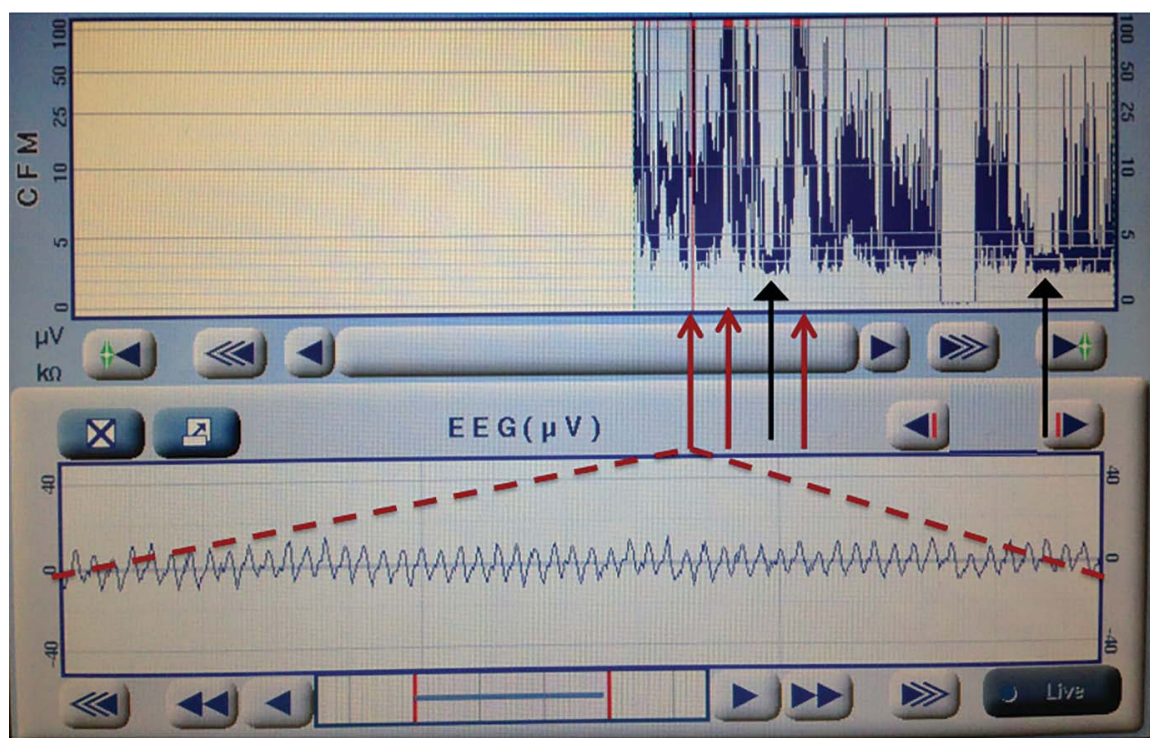

Amplitude-integrated EEG monitoring shows transient increases in amplitude concerning for possible seizures (red arrows) in contrast to baseline (black arrows). Concurrent raw EEG trace (dashed lines) shows an intermittent rhythmic pattern timelocked to the paroxysmal limb movements.

A newborn boy had a profound hypoxic-ischemic insult at birth. He developed rhythmic myoclonus within 1 hour, which was initially assumed to be seizures, but was unresponsive to escalating antiepileptic therapy. On careful examination, it was evident that myoclonus could be induced and suppressed. Amplitude-integrated (figure) and video EEG (video on the Neurology ${ }^{\circledR}$ Web site at Neurology.org) demonstrated a suppressed background with intermittent rhythmic pattern correlating with the movements. Laterality of this pattern changed with head positioning, suggesting artifact from pressure on dependent electrodes. Care was ultimately redirected when neuroimaging confirmed severe injury.

Nonepileptic myoclonus is a brainstem release phenomena ${ }^{1}$ that can be difficult to distinguish from seizures without detailed clinical examination combined with EEG. ${ }^{2}$ Timely diagnosis can prevent unnecessary treatment and can inform prognosis.

\section{AUTHOR CONTRIBUTIONS}

Dr. Walsh drafted the manuscript, created the figure, and approved all final changes. Dr. Baumer edited the manuscript, created the PowerPoint, and approved all final changes. Dr. Bernson-Leung edited the manuscript and approved all final changes. Dr. Lerou edited the manuscript and approved all final changes. Dr. Peters edited the manuscript, created the video file, and approved all final changes.

\section{STUDY FUNDING}

No targeted funding reported.

\section{DISCLOSURE}

B. Walsh and F. Baumer report no disclosures. M. Bernson-Leung is a member of the Editorial Board of the Neurology ${ }^{\circledR}$ Resident \& Fellow Section. P. Lerou and J. Peters report no disclosures. Go to Neurology.org for full disclosures.

\section{REFERENCES}

1. Huntsman RJ, Lowry NJ, Sankaran K. Nonepileptic motor phenomena in the neonate. Paediatr Child Health 2008;13: 680-684.

2. Mizrahi EM, Kellaway P. Characterization and classification of neonatal seizures. Neurology 1987;37:1837-1844.

\section{at Neurology.org}

Download teaching slides: Neurology.org 


\section{Neurology}

Teaching Video NeuroImages: Nonepileptic myoclonus in a neonate following severe hypoxic-ischemic injury

Brian H. Walsh, Fiona M. Baumer, Miya E. Bernson-Leung, et al.

Neurology 2015;84;e90

DOI 10.1212/WNL.0000000000001397

This information is current as of March 23, 2015

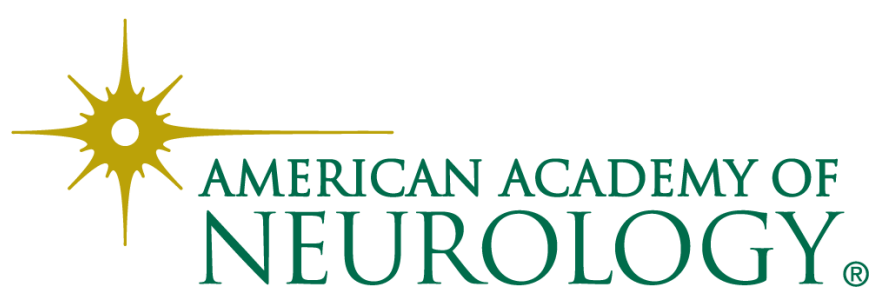




\section{Updated Information \& Services}

\section{Supplementary Material}

\section{References}

Subspecialty Collections

\section{Permissions \& Licensing}

\section{Reprints}

including high resolution figures, can be found at: http://n.neurology.org/content/84/12/e90.full

Supplementary material can be found at: http://n.neurology.org/content/suppl/2015/03/21/WNL.0000000000001 397.DC1 http://n.neurology.org/content/suppl/2015/03/21/WNL.0000000000001 397.DC2

This article cites 2 articles, 1 of which you can access for free at: http://n.neurology.org/content/84/12/e90.full\#ref-list-1

This article, along with others on similar topics, appears in the following collection(s):

EEG

http://n.neurology.org/cgi/collection/eeg_

Myoclonus

http://n.neurology.org/cgi/collection/myoclonus

Myoclonus; see Movement Disorders/myoclonus

http://n.neurology.org/cgi/collection/myoclonus_see_movement_disord ers-myoclonus

Neonatal

http://n.neurology.org/cgi/collection/neonatal

Neonatal seizures

http://n.neurology.org/cgi/collection/neonatal_seizures

Information about reproducing this article in parts (figures,tables) or in its entirety can be found online at:

http://www.neurology.org/about/about_the_journal\#permissions

Information about ordering reprints can be found online:

http://n.neurology.org/subscribers/advertise

Neurology ${ }^{\circledR}$ is the official journal of the American Academy of Neurology. Published continuously since 1951 , it is now a weekly with 48 issues per year. Copyright @ 2015 American Academy of Neurology. All rights reserved. Print ISSN: 0028-3878. Online ISSN: 1526-632X.

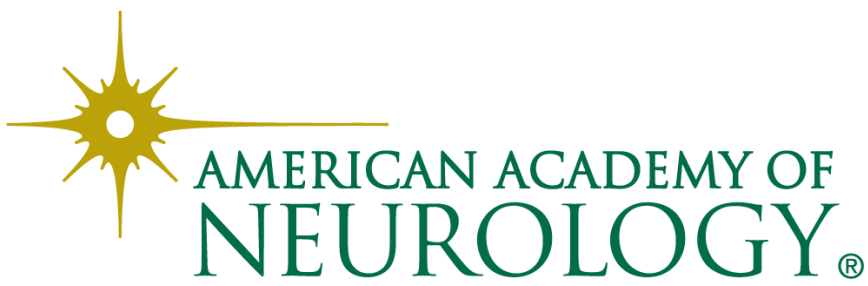

